\title{
PERILAKU ATTENTION DEFICIT HYPERACTIVITY DISORDER (ADHD) DALAM PROSES PEMBELAJARAN (STUDI KASUS PESERTA DIDIK) DI KELAS IV SD NEGERI GEJAYAN
}

\author{
Nugrahini Indra Umratun Wakhaj \\ Nurul Hidayati Rofiah \\ PGSD FKIP Universitas Ahmad Dahlan \\ indrasrara@gmail.com
}

\begin{abstract}
The behavior of primary school-age students today is very diverse, one of these behaviors are children who are very difficult to manage, can not be silent and as if not paying attention to the lessons in the classroom. These children usually experience emotional and behavioral disorders in its development of ADHD (Attention Deficit Hyperactivity Disorder). This study aims to describe the behavior and impact of Attention Deficit Hyperactivity Disorder (ADHD) in the learning process in grade 4 students of SD Negeri Gejayan.

This type of research is a type of Descriptive Qualitative research, with data collection techniques of observation, interview, and doumentation. The subjects in this research are DA fourth graders of SD Negeri Gejayan. While the data analysis techniques using data reduction, data presentation, and conclusions.

The results showed that there was Attention Deficit Hyperactivity Disorder (ADHD) behavior in the learning process in Grade IV of Gejayan State Elementary School which consisted of three behaviors: inattensi, hyperactive and impulsive behavior. The impact of Attention Deficit Hyperactivity Disorder (ADHD) behavior affects three aspects including (1) impact on learning process or education, (2) impact on student's behavior in learning process and, (3) impact to social aspect of student in process learning.

Keywords: Attention Deficit Hyperactivity Disorder (ADHD) Behavior in Learning Process

ABSTRAK

Perilaku peserta didik usia Sekolah Dasar saat ini sangat beragam, salah satu perilaku ini adalah anak-anak yang sangat sulit diatur, tidak bisa diam dan seolah-olah tidak memperhatikan pelajaran di kelas. Anak-anak tersebut biasanya mengalami gangguan emosi dan perilaku dalam perkembangannya yaitu ADHD (Attention Deficit Hyperactivity Disorder). Penelitian ini bertujuan untuk mendeskripsikan perilaku serta dampak Attention Deficit Hyperactivity Disorder (ADHD) dalam proses pembelajaran pada peserta didik kelas IV SD Negeri Gejayan.

Jenis penelitian ini merupakan jenis penelitian Deskriptif Kualitatif, dengan teknik pengumpulan data observasi, wawancara, dan doumentasi. Subyek dalam penelitian ini yaitu DA siswa kelas IV SD Negeri Gejayan. Sedangkan teknik analisis data menggunakan reduksi data, penyajian data, dan kesimpulan.
\end{abstract}


Hasil penelitian menunjukkan bahwa terdapat perilaku Attention Deficit Hyperactivity Disorder (ADHD) dalam proses pembelajaran di kelas IV SD Negeri Gejayan yang meliputi tiga perilaku yaitu perilaku inatensi, hiperaktif dan impulsif. Adapun dampak yang terjadi akibat perilaku Attention Deficit Hyperactivity Disorder (ADHD) mempengaruhi tiga aspek yang meliputi (1) dampak terhadap proses pembelajaran atau pendidikan, (2)dampak terhadap perilaku siswa dalam proses pembelajaran dan, (3) dampak terhadap aspek sosial siswa dalam proses pembelajaran.

Kata kunci: Perilaku Attention Deficit Hyperactivity Disorder (ADHD) dalam Proses Pembelajaran

\section{PENDAHULUAN}

Perilaku peserta didik usia Sekolah Dasar saat ini sangat beragam, salah satu perilaku ini adalah anak-anak yang sangat sulit diatur, tidak bisa diam dan seolah-olah tidak memperhatikan pelajaran di kelas. Anak-anak tersebut biasanya mengalami gangguan emosi dan perilaku dalam perkembangannya. Dalam kasus anak dengan gangguan emosi dan perilaku anak secara umum oleh Balitbang Direktorat Pendidikan Luar Biasa menemukan 696 siswa SD dari empat provinsi di Indonesia yang rata-rata nilai rapornya kurang dari 6, dinyatakan 33\% mengalami gangguan emosi dan perilaku. Sementara khusus pada anak tunalaras tipe ADHD (Attention Defict Hyperactivity Disorder) ternyata sering ditemukan di tengah masyarakat, terutama di perkotaan (Ilahi, 2013).

ADHD adalah suatu istilah populer yang merupakan kependekan dari Attention Defict Hyperactivity Disorder. Jika diartikan ke dalam bahasa Indonesia yaitu Gangguan Pemusatan Perhatian dan Hiperaktif (GPPH). Baihiqi dan Sugiarmin (2008) mengartikan ADHD dengan anak yang memperlihatkan simtom-simtom (ciri atau gejala) kurang konsentrasi, hiperaktif, dan implusif yang dapat menyebabkan ketidakseimbangan sebagian besar kegiatan hidup mereka. Sementara Kosasih dkk., (2012) mengartikan ADHD dengan gangguan perilaku yang ditandai dengan gangguan pemusatan perhatian, pembicaraan yang lepas kontrol, serta perilaku yang hiperaktif. Menurutnya, pada umumnya gangguan ADHD sering dijumpai pada anak sekolah dan mayoritas penderita gangguan ADHD ini adalah anak Laki-laki.

Menurut Wiyani (2014) anak dengan gangguan ADHD selalu memiliki tiga komponen ciri utama yang sama, yaitu inatensi (rentang perhatian yang kurang), impulsivitas yang berlebihan, dan adanya hiperaktif. Maksud dari inatensi adalah anak dengan gangguan ADHD ini tampak mengalami kesulitan dalam memusatkan perhatian. Anak dengan gangguan ADHD sangatlah mudah teralihkan oleh rangsangan yang tiba-tiba diterima oleh alat indranya atau oleh perasaan yang timbul pada saat itu. Hal itu akan memengaruhi proses penerimaan informasi dari lingkungannya. Kemudian, impulsivitas adalah suatu gangguan perilaku berupa tindakan yang tidak disertai dengan pemikiran. Anak dengan gangguan ADHD sangat dikuasai oleh perasaanya sehingga cepat bereaksi. Perilaku tersebut akan menyulitkan anak dengan gangguan ADHD maupun lingkungannya. Sementara hiperaktif merupakan suatu gerakan yang berlebihan melebihi gerakan yang dilakukan anak seusianya pada umumnya. Biasanya sejak bayi mereka banyak bergerak dan sulit untuk ditenangkan. Bila dibandingkan dengan individu yang aktif tetapi produktif, perilaku hiperaktif tampak tidak memiliki tujuan. Mereka kurang mampu mengontrol dan melakukan koordinasi dalam aktivitas motoriknya sehingga tidak dapat dibedakan mana gerakan yang penting dan mana gerakan yang tidak penting. Gerakannnya pun dilakukan secara terus menerus tanpa lelah sehingga mereka kesulitan untuk memusatkan perhatiannya. 
Berdasarkan hasil observasi dan wawancara terhadap guru kelas IV SD Negeri Gejayan peneliti menemukan peserta didik yang menunjukkan perilaku ADHD. Perilaku peserta didik ini ditandai dengan perilaku inatensi, hiperaktif dan impulsif. Perilaku inatensi meliputi ketidakmampuan siswa dalam berkonsentrasi dalam waktu yang lama dan tidak memperhatikan perintah guru. Perilaku hiperaktif meliputi tidak dapat duduk dengan keadaan tenang, mondar-mandir di dalam kelas, banyak melakukan gerakan tangan dan kaki yang berlebihan serta keluar masuk kelas dengan berbagai alasan. Selanjutnya perilaku impulsif siswa meliputi siswa tidak dapat menyelesaikan tugas yang diberikan oleh guru dan suka mengganggu teman-temannya ketika proses pembelajaran berlangsung. Gejala dari ADHD sangat kompleks sehingga guru maupun orang tua sulit untuk memutuskan apakah anak tersebut mengalami gangguan ADHD. Sebab sebagian perilaku yang merupakan gejala ADHD juga dapat ditemukan pada anak-anak umumnya, hanya kadarnya, waktu timbulnya gejala, dan penyebab muncul gejala tersebut yang berbeda.

Apabila perilaku ADHD dibiarkan begitu saja, akan memberikan dampak pada perkembangan jenjang pendidikan selanjutnya. ADHD juga akan memberi dampak pada perkembangan anak yang mengalami perilaku tersebut, seperti kurangnya perhatian terhadap pelajaran, anak sering gagal dan tidak dapat menyelesaikan tugas yang diberikan. Di dalam kelas anak dengan gangguan ADHD juga akan mengganggu proses belajarmengajar karena perilaku anak ADHD ini sering berteriak, berjalan atau berlari dan mengganggu teman lainnya sehingga memberi pengaruh negatif terhadap peserta didik lainnya dan kegiatan belajar mengajar tidak dapat berjalan dengan optimal.

Seburuk apapun tingkat penyimpangan perilaku gangguan ADHD yang dilakukan siswa, diharapkan masih memiliki potensi yang baik untuk belajar. Potensi tersebut diharapkan dapat dikembangkan agar siswa mendapatkan penilaian yang positif dari orangorang di sekitarnya. Terkait dengan karakteristik yang telah disebutkan, anak dengan gangguan ADHD perlu mendapat perhatian dan penanganan khusus. Berbagai penanganan untuk mengendalikan perilaku ADHD dapat dilakukan dengan berbagai teknik. Salah satu usaha untuk mengatasi perilaku ini perlu diadakan penelaahan secara mendetail. Dengan demikian perlu dilakukan penelitian yang berusaha memahami secara mendetail tentang suatu gejala, sebab dan akibat yang ditimbulkan oleh suatu kasus yang disebut dengan studi kasus.

Sesuai dengan latar belakang masalah dan rumusan masalah yang dikemukakan di atas, maka tujuan dari penelitian ini yaitu (1) Untuk mendeskripsikan perilaku Attention Deficit Hyperactivity Disorder (ADHD) dalam proses pembelajaran pada peserta didik kelas IV SD Negeri Gejayan.(2) Untuk mendeskripsikan dampak yang terjadi akibat perilaku Attention Deficit Hyperactivity Disorder (ADHD) dalam proses pembelajaran pada peserta didik kelas IV SD Negeri Gejayan.

Menurut Baihaqi dan Sugiarmin (2014) menyatakan bahwa ADHD menjelaskan kondisi anak-anak yang memperlihatkan simtom-simtom (ciri atau gejala) kurang konsentrasi, hiperaktif, mudah putus asa dan implusif yang dapat menyebabkan ketidakseimbangan sebagian besar aktivitas hidup mereka. Selanjutnya Barkley (1991) dalam Dayu (2014) mendefinisikan ADHD sebagai sebuah gangguan ketika respons terhalang dan mengalami disfungsi pelaksana yang mengarah pada kurangnya pengaturan diri, lemahnya kemampuan mengatur perilaku untuk tujuan sekarang dan masa depan, serta sulit beradaptasi secara sosial dan perilaku dengan tuntutan lingkungan. Jadi ADHD merupakan perilaku yang berkembang dan timbul pada anak-anak berupa kekurang mampuan dalam hal menaruh perhatian dan pengontrolan diri dengan memperlihatkan simtom-simtom (ciri atau gejala) kurang konsentrasi , hiperaktifitas yang sangat tinggi atau sangat banyak seperti terus menerus bergerak seakan-akan tidak mengenal akhir, atau tidak 
akan berhenti, mudah putus asa dan implusif yang dapat menyebabkan ketidakseimbangan sebagian besar aktivitas hidup mereka.

Osman (2002) memberikan tiga tipe ADHD yaitu (1) ADHD tipe kombinasi. Penyandang ini kurang mampu memperhatikan aktivitas permainan atau tugas, perhatiannya mudah pecah,. Selain mudah pendirian, implusif, dan selalu aktif, mereka juga tidak mampu asyik dalam kegiatan yang menghabiskan waktu, (2) ADHD tipe predominan kurang mampu memperhatikan. Penyandang ini terkadang tidak diperhatikan oleh para guru karena memiliki sifat pendiam dan kecil hati, tapi bukan berarti mereka tidak ada. Mereka tidak mendengarkan ketika di ajak bicara, dan kelihatannya tidak bisa mengikuti instruksi atau proyek, (3) ADHD Tipe Predominan Hiperaktif-Implusif. Penyandang ini cenderung terlalu energik, lari kesana kemari dan suka melompat. Meskipun demikian dan membuat heran setiap orang, mereka sering bisa menaruh perhatian di kelas dan kelihatan seakan sedang tidak mendengarkan

Selanjutnya Dayu (2014) membagi ADHD ke dalam 3 jenis yaitu (1) Tipe anak yang tidak bisa memusatkan perhatian. Mereka sangat mudah terganggu perhatiannya, tetapi tidak hiperaktif atau implusif. Mereka sangat sulit sekali memusatkan perhatiannya pada beberapa hal seperti membaca, menyimak pelajaran, atau melakukan permainan. Mereka juga sering kali melamun dan dapat digambarkan seperti sedang berada di awang-awang, (2) Tipe anak yang hiperaktif dan implusif. Mereka menunjukkan gejala yang sangat hiperaktif dan implusif tetapi mereka juga tidak bisa memusatkan perhatiannya. Tipe ini sering kali ditemukan pada anak-anak kecil, (3) Tipe gabungan. Pada tipe gabungan ini mereka sangat mudah sekali terganggu perhatiannya, hiperaktif, dan implusif. Kebanyakan anak dengan ADHD termasuk tipe seperti ini.

Terdapat kategori anak yang tergolong hyperactivy disorder menurut Ormrod (2011), Santrock (2009), dan Eggen (2004) dalam Surna dan Pandeirot (2014:206) yaitu (1) Attention. Anak yang tergolong pada kategori ini mengalami kesulitan untuk memfokuskan perhatian dan menjaga kestabilan perhatian, terutama dalam mengerjakan tugas. Anak mengalami kesulitan mendengar dan mengikuti perintah, sering membuat kekeliruan, dan salah paham atau sangat mudah melakukan hal-hal di luar dugaan. (2) Hyperactivity. Anak yang tergolong kategori ini tampaknya memiliki tenaga yang berlebihan, bergerak dengan tidak berarah ke mana saja semaunya tanpa memperhatikan orang lain atau aturan yang berlaku, dan sering membuat keributan di antara teman sebaya. (3) Impulsivity. Anak yang tergolong kategori ini memiliki kesulitan berperilaku yang sesuai dengan tuntutan lingkungan dan tidak memperhitungkan risiko yang akan ditimbulkan. Perilakunya tibatiba muncul secara spontan tanpa pernah memperhatikan lingkungan yang tidak pernah memikirkan apa dampak dari perbuatannya. Gejala atau ciri-ciri ADHD juga dijelaskan oleh Cahya (2013). Ciri-ciri tersebut adalah (1) Inatensi atau gangguan pemusatan perhatian. Individu dengan gangguan ADHD mengalami kesulitan untuk memusatkan perhatiannya. Perhatian mereka sangat mudah teralihkan oleh rangsangan yang diterima oleh alat indra secara tiba-tiba. Oleh karena itu anak dengan gangguan ini hanya mampu memperhatahankan suatu aktivitas atau tugas dalam jangka waktu yang pendek. (2) Hiperaktif. Anak dengan gangguan ADHD selalu terlihat melakukan gerakan yang berlebihan dibandingkan dengan yang dilakukan anak-anak seusianya secara umum. Perilaku hiperaktif ini tampak tidak bertujuan jika dibandingkan dengan perilaku individu yang aktif, tetapi produktif. Anak-anak dengan penyandang gangguan ADHD tidak mampu mengontrol dan melakukan koordinasi dalam aktivitas motoriknya. Hingga sulit dibedakan mana gerakan yang penting dan mana yang tidak penting. Mereka melakukan gerakan secara terus-menerus tanpa lelah. (3) impulsive Anak ADHD mengalami gangguan 
perilaku berupa melakukan tindakan tanpa memikirkannya terlebih dahulu. Mereka sangat dikuasai oleh perasaannya sehingga cepat sekali bereaksi.

Cahya (2013: 6) menyebutkan faktor-faktor tersebut antara lain: (1) Faktor Genetik. Faktor genetika atau keturunan merupakan penyebab terbanyak dalam kasus ADHD. Cahya (2013: 6) dalam Greene (2005) memaparkan bahwa berdasarkan riset di Amerika, diketahui sekitar 30\% dari seluruh anak yang menderita ADHD setidaknya salah satu orangtuanya menderita ADHD. Selanjutnya perbedaan-perbedaan pada fungsi dan kimiawi otak kemungkinan besar disebabkan oleh faktor keturunan karena ia dapat diwariskan secara genetik. (2) Ketidakseimbangan Kimia Otak. Ketidakseimbangan kimiawi pada otak (neurotransmitter) yaitu zat-zat yang mengantarkan impuls saraf di dalam otak diyakini para ahli sebagai salah satu faktor yang dapat menjadi penyebab timbulnya ADHD. (3) Kinerja Otak. Pada anak-anak dengan gangguan ADHD, rea otak yang mengontrol perhatian didapati kurang aktif dibandingkan dengan anak-anak lainnya yang menderita ADHD. (4) Paparan Zat-zat Beracun Paparan zat-zat beracun misalnya polusi udara dengan kandungan timbal yang tinggi dapat memengaruhi perkembangan otak anak dan menyebabkan hiperaktivitas. Cat yang berbau menyengat dan saluran pipa yang berkarat merupakan benda yang juga mengandung toksik berbahaya yang dapat menjadi penyebab timbulnya ADHD. (5) Asap Rokok. Nikotin di dalam rokok yang dikonsumsi oleh ibu hamil diduga dapat mengakibatkan janin mengalami kekurangan suplai oksigen ke otak sehingga menimbulkan kerusakan pada otak dan menyebabkan timbulnya ADHD. Selain itu asap rokok yang dapat menyebabkan ADHD pada anak dapat pula berasal dari lingkungan sekitar yang dipenuhi asap rokok, yang terisap oleh ibu hamil, juga asap rokok yang berasal dari ibu yang merokok yang terisap oleh bayi pada masa sesudah melahirkan. (6) Konsumsi Alkohol Selama Masa Kehamilan. Kebiasaan ibu mengkonsumsi minuman beralkohol kemungkinan besar dapat mengakbiatkan anak dalam kandungannya kelak tumbuh menjadi penderita ADHD. Hal ini karena zat-zat yang terkandung dalam alkohol dapat memengaruhi gangguan yang mengindikasikan terjadinya gangguan hiperaktivitas. (7) Faktor-faktor Lain. Faktor lain yang dapat menyebabkan gangguan ADHD yaitu makanan dengan kadar gula dan zat aditif yang tinggi, cidera kepala yang terjadi pada proses kelahiran atau sesudah kelahiran dan penggunaan obat-obatan berlebihan, gizi buruk, vaksin-vaksin, suasana di dalam keluarga yang kacau, dan ibu yang tidak peduli pada anaknya adalah sejumlah faktor yang oleh sebagian kalangan diyakini berkontribusi terhadap munculnya gangguan ADHD pada anak.

Cahya (2013: 12) dalam Sugiarmin (2007) mengemukakan bahwa pengaruh ADHD dapat dilihat dalam tiga bidang utama, yaitu: (1) Pengaruh ADHD terhadap Pendidikan. Meliputi tidak dapat segera memulai suatu kegiatan, prestasi kurang, bekerja terlalu lambat atau cepat, melupakan instruksi atau penjelasan, tidak melakukan tugas, selalu meninggalkan benda-benda, selalu bingung, motivasi yang kurang, kesulitan mengerjakan tugas, menghindari teman dan berperilaku kacau. (2) Pengaruh ADHD Terhadap Perilaku. Meliputi menuntut, turut campur dengan orang lain, mudah frustasi, kurang mengendalikan diri, tidak tenang/gelisah, lebih banyak bicara, suka menjadi pemimpin, mudah berubah pendirian, menganggu, mudah bingung (3) Pengaruh ADHD Terhadap Aspek Sosial. Meliputi mementingkan diri sendiri, egosentris, cemas, kasar dan tidak peka, tidak dewasa dan tertekan, harga diri rendah, keras/tenang dan membuat keributan, tidak berpikir panjang, menarik diri dari kelompok, sering berperilaku tanpa perasaan, tidak mau menunggu giliran. 


\section{METODE PENELITIAN}

Penelitian merupakan penelitian kualitatif yang bersifat deskriptif. Moleong (2012) menyatakan bahwa penilitian kualitatif merupakan penelitian yang bermaksud untuk memahami fenomena tentang apa yang dialami oleh subyek penelitian yang berupa perilaku, persepsi, motivasi, tindakan, secara holistik, yang dilakukan dengan cara deskripsi dalam bentuk kata-kata dan bahasa, pada suatu konteks khusus yang alamiah dan dengan memanfaatkan berbagai metode alamiah. Penelitian kualitatif deskriptif ini menggunakan studi kasus. Menurut Azwar (2014) studi kasus merupakan penyelidikan mendalam (indepth study) mengenai suatu unit sosial sedemikian rupa sehingga menghasilkan gambaran yang terorganisasikan dengan baik dan lengkap mengenai unit sosial tersebut. Penelitian studi kasus berupaya menelaah sebanyak mungkin data mengenai subjek yang diteliti.

Penelitian jenis deskriptif ini akan digunakan untuk mendeskripsikan mengenai bentuk-bentuk perilaku anak ADHD serta dampak akibat perilaku anak ADHD pada proses pembelajaran di kelas IV SD Negeri Gejayan. Adapun studi kasus dalam penelitian ini adalah menelaah secara mendalam dan menggali data sebanyak-banyaknya tentang bentukbentuk perilaku anak ADHD pada proses pembelajaran di kelas IV SD Negeri Gejayan.

Penelitian ini dilaksanakan pada siswa kelas IV SD Negeri Gejayan yang beralamatkan di Jalan Anggajaya III Gejayan Condongcatur Depok Sleman. ini Subjek penelitian ini adalah siswa yang mengalami gangguan ADHD di kelas IV SD Negeri Gejayan. Objek penelitian dalam penelitian ini yaitu bentuk-bentuk perilaku anak ADHD serta dampak perilaku ADHD pada proses pembelajaran di kelas IV SD Negeri Gejayan. Teknik pengumpulan data yang digunakan pada penelitian ini dijabarkan sebagai berikut: (1) Observasi, Data yang dikumpulkan dengan observasi dalam penelitian ini berkaitan dengan bentuk-bentuk perilaku anak ADHD serta dampak yang timbul akibat perilaku anak ADHD dalam proses pembelajaran. Penulis mengamati bentuk-bentuk perilaku anak ADHD selama proses pembelajaran. (2) Wawancara Selain teknik observasi dalam penelitian ini juga menggunakan teknik wawancara. Wawancara yang penulis gunakan adalah wawancara terstruktur dimana dalam melakukan wawancara ini fungsi peneliti sebagian besar hanya mengajukan pertanyaan dan subjek penelitian hanya bertugas menjawab pertanyaan saja. Selama proses wawancara harus sesuai dengan pedoman wawancara yang telah dipersiapkan. Adapun yang menjadi terwawancara dalam penelitian ini adalah subjek utama, yaitu: DA (nama samaran) yang merupakan siswa yang mengalami gangguan ADHD untuk memperoleh data perilau subjek. Informan, yaitu Guru kelas IV SD Negeri Gejayan untuk memperoleh data secara spesifik tentang seperti apa bentuk-bentuk perilaku anak ADHD serta dampak akibat perilaku anak ADHD tersebut dalam proses pembelajaran di kelas, pendamping atau orang tua siswa DA untuk memperoleh data terkait kebiasaan siswa. Dokumentasi, Dalam penelitian ini metode dokumentasi digunakan untuk mengumpulkan data yang berhubungan dengan anak dari dokumentasi berupa rekaman wawancara dengan subjek, foto subjek ketika proses pembelajaran di kelas.

Metode yang digunakan dalam menguji keabsahan data penelitian ini adalah trianggulasi. Moleong (2012:330) menyatakan bahwa trianggulasi adalah teknik pemeriksaan keabsahan data yang memanfaatkan sesuatu yang lain. Di luar data itu untuk keperluan pengecekan atau sebagai pembanding terhadap data itu. Teknik trianggulasi yang paling banyak digunakan ialah pemeriksaan melalui sumber lainnya. Trianggulasi yang digunakan dalam penelitian sini yaitu trianggulasi sumber data. Tindakan dalam penelitian ini adalah membandingkan data dari pengamtan dengan wawancara yang dimaksudkan yaitu data hasil observasi bentuk perilaku anak ADHD dan akibat perilaku anak ADHD dalam proses pembelajaran di kelas. Kemudian membandingkan hasil 
wawancara antara satu sumber dengan sumber lain yaitu membandingkan wawancara antara guru kelas dan orang tua. Serta membandingkan hasil wawancara analisi dokumentasi yang berkaitan, dalam hal ini membandingkan hasil wawancara guru kelas, kepala sekolah dengan analisis dokumentasi melalui dokumen yang berkaitan dengan bentuk-bentuk perilaku anak ADHD.

Proses analisis data menggunakan model Miles dan Huberman, yaitu reduksi data (Data Reduction), penyajian data (Display Data), penarikan kesimpulan (Verification). Kesimpulan dalam penelitian kualitatif adalah merupakan temuan baru yang sebelumnya belum pernah ada. Temuan dapat berupa deskripsi atau gambaran suatu obyek yang sebelumnya masih remang-remang atau gelap sehingga setelah diteliti menjadi jelas, dapat berupa hubungan kasual atau interaktif, hipotesis atau teori.

\section{HASIL DAN PEMBAHASAN}

Penelitian ini dilaksanakan di SD Negeri Gejayan beralamatkan di Jalan Anggajaya III Gejayan Desa Condongcatur Kecamatan Depok Kabupaten Sleman, DIY. SD Negeri Gejayan ini berdiri pada Tahun 1974 dengan luas tanah $2.311,5 \mathrm{~m}^{2}$ dan luas bangunan $1.289 \mathrm{~m}^{2}$ serta status kepemilikan tanah adalah milik Sultan Ground atau Pemerintah kabupaten Sleman. Kondisi guru dan karyawan tahun 2017 di SD Negeri Gejayan terdapat 10 tenaga pendidik dengan pendidikan terakhir sarjana (S1), 1 tenaga pendidik dengan pendidikan terakhir diploma (D3), 1 tenaga pendidik dengan pendidikan terakhir Sekolah Pendidikan Guru (SPG), serta 2 karyawan dengan pendidikan terakhir Sekolah Lulusan Tingkat Akhir (SLTA) Dalam pembahasan ini akan dibahas lebih lanjut mengenai perilaku Attention Deficit Hyperactivity Disorder (ADHD) dalam proses pembelajaran pada peserta didik kelas IV SD Negeri Gejayan dan dampak yang terjadi akibat perilaku Attention Deficit Hyperactivity Disorder (ADHD) dalam proses pembelajaran pada peserta didik kelas IV SD Negeri Gejayan.

1. Perilaku Attention Deficit Hyperactivity Disorder (ADHD) dalam proses pembelajaran pada peserta didik kelas IV SD Negeri Gejayan. Berdasarkan hasil wawancara observasi, dan dokumentasi diperolehgambaran tentang perilaku Attention Deficit Hyperactivity Disorder (ADHD) dalam proses pembelajaran pada peserta didik kelas IV SD Negeri Gejayan yang meliputi perilaku inatensi, hiperaktif, dan impulsif adalah sebagai berikut:

a. Inatensi

Berdasarkan hasil wawancara, observasi, dan dokumentasi diperoleh gambaran bahwa bahwa perilaku inatensi siswa ADHD dalam proses pembelajaran di kelas IV SD Negeri Gejayan yaitu siswa sangat sulit untuk memusatkan perhatian dan perhatiannya sangat mudah teralihkan terutama oleh rangsang suara dari dalam maupun dari luar kelas, ketika orang lain berbicara siswa tampak bersikap cuek tidak mendengarkan dan tidak dapat bertatapan langsung dengan orang tersebut, siswa kerap melakukan kesalahan akibat kurang berhati-hati atau kurang memperhatikan, sering melupakan atau menghilangkan benda-benda, sering sekali tidak menyelesaikan tugas yang diberikan oleh guru hingga tuntas karena siswa tidak dapat duduk dengan tenang dan terlalu banyak melakukan aktivitas fisik ketika proses pembelajaran berlangsung. Hal tersebut sesuai dengan pendapat yang dijelaskan oleh Cahya (2013: 8), individu dengan gangguan ADHD mengalami kesulitan untuk memusatkan perhatiannya. Perhatian mereka sangat mudah teralihkan oleh rangsangan yang diterima oleh alat indra secara tiba-tiba. 
Oleh karena itu anak dengan gangguan ini hanya mampu memperhatahankan suatu aktivitas atau tugas dalam jangka waktu yang pendek.

b. Hiperaktif

Berdasarkan hasil wawancara, observasi, dan dokumentasi diperoleh gambaran bahwa perilaku hiperaktif siswa ADHD dalam proses pembelajaran di kelas IV SD Negeri Gejayan yaitu siswa DA tidak dapat duduk dengan tenang, sering bergerak seperti berlari keluar masuk kelas, sering memanjat bangku dan meja di kelas, mempunyai kebutuhan untuk selalu bergerak seperti sulit diam, menggeliat, gelisah, dan sering berdiri kembali ketika duduk. Selain itu dalam proses pembelajaran DA lebih banyak bicara dan suka berteriak-teriak ketika DA penasaran terhadap sesuatu dan ada suatu hal yang tidak DA suka. Perilaku hiperaktif lainnya yang dialami oleh DA yaitu sering mengganggu teman ketika proses pembelajaran berlangsung sehingga menimbulkan kegaduhan di dalam kelas. Siswa juga suka membuat suara dari barang barang disekitarnya yang membuat berisik. Hal ini sesuai dengan pendapat yang dijelaskan oleh Ormrod (2011), Santrock (2009), dan Eggen (2004) dalam Surna dan Pandeirot (2014:206), anak yang tergolong kategori hiperaktif tampaknya memiliki tenaga yang berlebihan, bergerak dengan tidak berarah ke mana saja semaunya tanpa memperhatikan orang lain atau aturan yang berlaku, dan sering membuat keributan di antara teman sebaya.

c. Impulsif

Berdasarkan hasil wawancara, observasi, dan dokumentasi diperoleh gambaran bahwa bahwa perilaku impulsif siswa ADHD dalam proses pembelajaran di kelas IV SD Negeri Gejayan yaitu siswa yaitu siswa DA sulit menunggu giliran ketika siswa yang lain baris untuk antri mengoreksi tugas kepada guru, DA menyela pembicaraan ketika guru berkomunikasi dengan siswa lain. Terkadang DA juga akan menjawab pertanyaan sebelum diberi kesempatan ketika DA sudah mengetahui topik pembahasannya sehingga DA terkesan memiliki keingintahuan yang besar. Selain itu dalam proses pembelajaran DA bertindak impulsif tanpa memikirkan konsekuensinya seperti mengejar sesuatu yang berbahaya dan sering membawa benda tajam serta sering memukul temannya tanpa sebab. Perilaku impulsif lainnya yang dialami oleh DA yaitu sering mengambil mainan teman dengan paksa, ketika DA tidak mendapatkan mainan tersebut DA akan bertindak semaunya sendiri. DA bertindak secara reaktif ketika ada teman yang mengeledeki dan sering bertindak tanpa dipikir terlebih dahulu serta menganggap bahwa hal tersebut adalah hal yang biasa. Hal ini sesuai dengan pendapat yang dijelaskan oleh Ormrod (2011), Santrock (2009), dan Eggen (2004) dalam Surna dan Pandeirot (2014:206), anak yang tergolong kategori impulsif memiliki kesulitan berperilaku yang sesuai dengan tuntutan lingkungan dan tidak memperhitungkan risiko yang akan ditimbulkan. Perilakunya tiba-tiba muncul secara spontan tanpa pernah memperhatikan lingkungan yang tidak pernah memikirkan apa dampak dari perbuatannya.

Berdasarkan hasil wawancara, observasi, dan dokumentasi diperoleh kesimpulan bahwa subyek AD termasuk tipe atau jenis ADHD gabungan. Hal ini dikarenakan AD 
sangat mudah sekali terganggu perhatiannya, hiperaktif, dan implusif (Dayu , 2014:30).

2. Dampak yang terjadi akibat perilaku Attention Deficit Hyperactivity Disorder (ADHD) dalam proses pembelajaran pada peserta didik kelas IV SD Negeri Gejayan. Berdasarkan hasil wawancara, observasi, dan dokumentasi diperoleh gambaran tentang dampak yang terjadi akibat perilaku Attention Deficit Hyperactivity Disorder (ADHD) dalam proses pembelajaran pada peserta didik kelas IV SD Negeri Gejayan yang meliputi dampak terhadap pendidikan, perilaku dan aspek sosial.

a. Dampak Terhadap Pendidikan dalam Proses Pembelajaran

Berdasarkan hasil wawancara, observasi, dan dokumentasi diperoleh gambaran terkait dampak akibat perilaku siswa ADHD terhadap pendidikan siswa dalam proses pembelajaran. Dampak tersebut yaitu siswa DA tidak dapat segera memulai kegiatan yang diperintahkan oleh guru dan DA akan memulai suatu kegiatan setelah diperintahkan oleh guru secara berkali-kali. Motivasi dan prestasi belajar siswa kurang karena siswa susah untuk memperhatikan pelajaran dikelas dan sering tidak mengerjakan tugas yang diberikan guru. Siswa dapat mengerjakan tugas ketika siswa tersebut didampingi secara personal. terkadang siswa dapat mengerjakan suatu hal dengan cepat dan terkadang juga sangat lambat, ketika diberikan intruksi atau penjelasan siswa terlihat cuek dan hanya ditinggal pergi.

b. Dampak Terhadap Perilaku dalam Proses Pembelajaran.

Berdasarkan hasil wawancara, observasi, dan dokumentasi diperoleh gambaran terkait dampak akibat perilaku siswa ADHD terhadap perilaku siswa dalam proses pembelajaran. Dampak tersebut yaitu siswa DA suka menuntut agar orang lain mengikuti apa yang siswa inginkan., DA turut campur dengan kegiatan orang lain seperti mengikuti teman ketika teman diminta maju ke depan kelas oleh guru dan ketika siswa DA bosan dengan suatu hal maka siswa akan cepat frustasi. Selain itu siswa DA tidak dapat mengendalikan diri ketika DA marah dengan temannya dan berbuat semaunya sendiri, tidak dapat tenang/gelisah serta sering berganti aktivitas. Dampak lain yang terjadi akibat perilaku ADHD yaitu siswa DA lebih banyak bicara ketika siswa tidak menyukai sesuatu dan hal itu akan dibicarakan oleh siswa secara berulang-ulang, siswa DA suka menjadi pemimpin dan mudah berubah pendirian, mudah bingung ketika mengerjakan sesuatu, mudah bosan dan sering berjalan-jalan di dalam kelas mengganggu teman ketika proses pembelajaran berlangsung.

c. Dampak Terhadap Aspek Sosial dalam Proses Pembelajaran

Berdasarkan hasil wawancara, observasi, dan dokumentasi diperoleh gambaran perilaku siswa ADHD dalam proses pembelajaran di kelas IV SD Negeri Gejayan yang memberikan dampak terhadap aspek sosial siswa. Dampak tersebut yaitu siswa DA tidak berpikir panjang dalam melakukan sesuatu terhadap teman, suka mementingkan diri sendiri dengan merebut barang milik teman dengan paksa sehingga menimbulkan perkelahian maupun keributan. Selain itu dampak yang timbul akibat perilaku ADHD terhadap aspek sosial siswa yaitu siswa tidak dapat menunggu giliran dan ketika mengerjakan tugas kelompok siswa suka menarik diri dari kelompok, siswa dapat bergabung dengan teman 
dengan kelompok hanya di waktu awal saja kemudian siswa akan pergi berjalanjalan dan mengganggu teman dikelas.

\section{KESIMPULAN}

Berdasarkan hasil penelitian tentang perilaku Attention Deficit Hyperactivity Disorder (ADHD) dalam proses pembelajaran pada peserta didik kelas IV SD Negeri Gejayan, maka diperoleh kesimpulan yaitu, perilaku siswa DA yang terjadi dalam proses pembelajaran di kelas IV SD Negeri Gejayan meliputi tiga perilaku yaitu inatensi, hiperaktif dan impulsif sehingga siswa termasuk tipe atau jenis ADHD gabungan. Dampak yang terjadi akibat perilaku siswa DA dalam proses pembelajaran di kelas IV SD Negeri Gejayan meliputi: (1) dampak terhadap pendidikan dalam proses pembelajaran, (2) dampak terhadap perilaku siswa dalam proses pembelajaran, (3) dampak terhadap aspek sosial dalam proses

\section{DAFTAR PUSTAKA}

Azwar, Saifuddin. 2014. Metode Penelitian. Yogyakarta: Pustaka Pelajar

Cahya, Laili S. 2013. ADHD Bisa Sembuh Kok. Yogyakarta: Familia.

Dayu P.A. 2014. Mendidik Anak ADHD. Yogyakarta:Javalitera

Herdiansyah, Haris. 2015. Wawancara, Observasi, dan Focus Groups. Jakarta: Rajawali Pers.

Moleong, Lexy J. 2012. Metodologi Penelitian Kualitatif. Bandung: Remaja Rosdakarya.

Osman, Betty B. 2002. Lemah Belajar dan ADHD. Jakarta:Gramedia Widiasarana Indonesia.

Surna, I Nyoman dan Pandeirot Olga D. 2014. Psikologi Pendidikan 1. Jakarta. Erlangga.

Wiyani, Ardi Novan. 2014. Penanganan Anak Usia Dini Berkebutuhan Khusus. Yogyakarta:Ar-Ruzz Media. 